\title{
Penerapan Model Pembelajaran CIRC (Cooperative Integrated Reading and Composition) untuk Meningkatkan Hasil Belajar PPKn
}

\section{Nyoman Alit Budiani*}

SMAN 1 Denpasar

\section{A R T I C L E I N F O \\ Article history: \\ Received 20 May 2019 \\ Received in revised form \\ 10 June 2019 \\ Accepted 30 July 2019 \\ Available online 28 \\ August 2019}

Kata Kunci:

Model pembelajaran CIRC, Hasil belajar PPKn

Keywords:

CIRC learning model, PPKn

learning outcomes

\begin{abstract}
A B S T R A K
Penelitian Tujuan dari penelitian ini adalah untuk mengetahui peningkatan hasil belajar PPKn siswa kelas X MIA 2 SMAN 1 Denpasar semester II tahun pelajaran 2018/2019 setelah diterapkan model pembelajaran CIRC (Cooperative Integrated Reading And Composition). Jenis penelitian ini adalah penelitian tindakan kelas (PTK) dengan subjek penelitian adalah siswa kelas X MIA 2 Semester II yang berjumlah 36 orang siswa. Data hasil belajar siswa dikumpulkan dengan tes pilihan ganda. Data yang diperoleh dianalisis menggunakan analisis statistik deskriptif. Berdasarkan penelitian yang telah dilakukan, dapat disimpulkan bahwa: penerapan model pembelajaran CIRC (Cooperative Integrated Reading And Composition) secara efektif dapat meningkatkan hasil belajar PPKn siswa kelas X MIA 2 semester II di SMAN 1 Denpasar tahun pelajaran 2018/2019. Hal tersebut ditunjukkan dari rerata pada siklus I sebesar 73,19 dengan ketuntasan klasikal $77,78 \%$. Sedangkan rerata pada siklus II sebesar 86,25 dengan ketuntasan klasikal 91,67\%.
\end{abstract}

\section{A B S T R A C T}

The purpose of this study was to determine the increase of PPKn learning outcomes for students of tenth grsde MIA 2 of SMAN 1 Denpasar in semester II of the 2018/2019 academic year after applying the CIRC (Cooperative Integrated Reading And Composition) learning model. This type of research was a classroom action research with research subjects were tenth grade MIA 2 students Semester II, amount to 36 students. Student learning outcomes data collected by multiple choice test.. The data obtained analyzed using descriptive statistical analysis. Based on the research that has been done, it can be concluded that: the application of the CIRC (Cooperative Integrated Reading And Composition) learning model can effectively improve the learning outcomes of PPKn in tenth MIA 2 students in the second semester at SMAN 1 Denpasar 2018/2019 academic year. It showed from the average in the first cycle wass 73.19 with $77.78 \%$ classical completeness. While the average in the second cycle was 86.25 with a classical completeness was $91.67 \%$. 


\section{Pendahuluan}

Pendidikan merupakan hal yang sangat penting bagi manusia. Dengan mengikuti program pendidikan, maka sumber daya manusia yang dimiliki akan semakin meningkat, baik itu dalam hal meningkatnya kemampuan kognitif, afektif maupun psikomotor dari manusia itu sendiri. Pendidikan pada era globalisasi saat ini merupakan aspek yang terpenting untuk dimiliki, dikarenakan pendidikan dapat memberikan manusia suatu pemahaman baru terkait dengan pandangan hidup bermasyarakat dalam konteks global atau mendunia. Dengan adanya pendidikan maka manusia dapat mengembangkan segala kemampuan yang dimilikinya. Menyadari begitu pentingnya pendidikan maka sekolah yang ada harus mampu membantu siswa memproleh pendidikan secara optimal. Sehingga mendapatkan prestasi belajar yang sesuai dengan harapan.

Menurut Undang-Undang Sistem Pendidikan Nasional No.20 Tahun 2003 pasal 1 butir 1, pendidikan adalah: "usaha sadar dan terencana untuk mewujudkan suasana belajar dan proses pembelajaran agar peserta didik secara aktif mengembangkan potensi dirinya untuk memiliki kekuatan spiritual keagamaan, pengendalian diri, kepribadian, kecerdasaan, akhlak mulia, serta keterampilan yang diperlukan dirinya, masyarakat, bangsa dan Negara." Pendidikan nasional bertujuan: "untuk mengembangkan potensi peserta didik agar menjadi manusia yang beriman dan bertakwa kepada Tuhan Yang Maha Esa, berakhlak mulia, cakap, kreatif, mandiri, dan menjadi waarga Negara yang demokratis serta bertanggung jawab" (UU Sisdiknas No. 20 tahun 2003 pasal 3).

Pendidikan juga merupakan modal bagi manusia dalam mempertahankan peradabannya, yang telah mengatur manusia mencapai suatu kesuksesan, serta pula yang gagal mengimplementasikan dalam kehidupan sehari- hari. Proses pendidikan telah terjadi dalam waktu yang lama, berbagai carapun telah ditempuh agar terjadi pemindahan pengetahuan pada generasi berikutnya. Pendidikan dilaksanakan dan melibatkan bermacam unsur dari komponen masyarakat. Hal ini sesuai dengan kutipan di bawah ini; Undang-Undang Dasar 1945. Pasal 31 Ayat 3 berbunyi: pemerintah mengusahakan dan menyelenggarakan satu sistem pendidikan nasional, yang meningkatkan keimanan dan ketaqwaan serta akhlak mulia dalam rangka mencerdaskan kehidupan bangsa, yang diatur dengan undang-undang (Fitriani, 2017).

Tuntutan perubahan mendasar di atas lanjut Wahab (2006:61) direspon oleh berbagai elemen dalam masyarakat, termasuk elemen fundamental, yaitu pendidikan yang bertanggung jawab untuk mengembangkan manusia-manusia, warga negara/warga masyarakat yang memiliki ciri-ciri seperti dikemukakan di atas. Pendidikan sebagai elemen dalam proses perubahan bermasyarakat, berbangsa dan bernegara, sebagaimana ditegaskan dalam rumusan Pasal 3 UU No. 20 Tahun 2003 tentang Sistem Pendidikan kemampuan dan membentuk watak serta peradaban bangsa yang bermartabat dalam rangka mencerdaskan kehidupan bangsa "berkembangnya potensi peserta didik aga bertakwa kepada Tuhan Yang Maha Esa, berakhlak mulia, sehat, berilmu, cakap, kreatif, mandiri, dan menjadi warganegara yang demokratis serta bertanggung jawab". Pembentukan watak dan peradaban bangsa yang bermartabat dalam rangka mencerdaskan kehidupan bangsa, dan menjadikan manusia sebagai warganegara yang demokratis dan bertanggung jawab secara filosofis, sosio-politis dan psikopedagogis, merupakan (mission sacre) dari pendidikan kewarganegaraan (Winataputra, 2006). Pendidikan kewarganegaraan tentu saja membawa implikasi dalam proses pembelajaran pendidikan kewarganegaraan di sekolah (sebagai mata pelajara). PKn di sekolah merupakan "mata pelajaran yang memfokuskan pada pembentukan warga negara yang memahami dan mampu melaksanakan hak-hak dan kewajibannya untuk menjadi warga negara Indonesia yang cerdas, terampil, dan berkarakter yang diamanatkan oleh Pancasila dan UUD 1945". (Ihsan, 2017).

Pengertian secara khusus, karakter adalah nilai-nilai yang khas baik (tahu nilai kebaikan, mau berbuat baik, nyata berkehidupan baik, dan berdamak baik terhadap lingkungan) yang terpatri dalam diri dan terwujud dalam perilaku. Dalam hubungannya dengan pendidikan, pendidikan karakter dapat dimaknai sebagai pendidikan nilai, pendidikan budi pekerti, pendidikan moral, pendidikan watak, yang bertujuan mengembangkan kemampuan siswa untuk memberikan keputusan baik buruk, memelihara kebaikan, mewujudkan dan menebar kebaikan dalam kehidupan sehari-hari dengan sepenuh hati. Pendidikan karakter berpijak dari karakter dasar manusia, yang bersumber dari nilai moral universal (bersifat absolut) sebagai pengejawantahan nilai-nilai agama yang biasa disebut the golden rule. Pendidikan karakter dapat memiliki tujuan yang pasti, apabila berpijak dari nilai-nilai karakter dasar tersebut. Menurut para ahli psikolog, beberapa nilai karakter dasar tersebut adalah: cinta kepada Allah dan ciptaan-Nya (alam dengan isinya), tanggung jawab, jujur, hormat dan santun, kasih sayang, peduli, kerjasama, percaya diri, kreatif, kerja keras, pantang menyerah, keadilan kepemimpinan, baik, rendah hati, toleransi, cinta damai dan cinta persatuan (Ayu, 2017). 
Menurut Suprijono (2012:5), hasil belajar adalah polapola perbuatan, nilai-nilai, pengertianpengertian, sikapsikap, apresiasi dan keterampilan. Selanjutnya Supratiknya (2012 : 5) mengemukakan bahwa hasil belajar yang menjadi objek penilaian kelas berupa kemampuan-kemampuan baru yang diperoleh siswa setelah mereka mengikuti proses belajar-mengajar tentang mata pelajaran tertentu. Dalam sistem pendidikan nasional rumusan tujuan pendidikan mengacu pada klasifikasi hasil belajar dari Bloom yang secara garis besar yaitu aspek kognitif, aspek afektif dan aspek psikomotor (Widodo, 2013).

Salah satu mata pelajaran yang diberikan di Sekolah Menengah Atas adalah Pendidikan Kewarganegaraan. Pendidikan kewaganegaraan merupakan bidang studi yang mencakup lintas bidang keilmuan karena dalam pendidikan kewarganegaraan terdapat pula pokok ilmu politik kemudian berkembang konsep civics yang berarti warga negara kemudian berkembang menjadi civics education yang selanjutnya diadaptasi menjadi pendidikan kewarganegaraan.

Pendidikan kewarganegaraan di sekolah bertujuan menghasilkan peserta didik yang memiliki budi pekerti dan selalu berpikir kritis dalam menanggapi isu kewarganegaraan serta selalu berpartisipasi aktif dan bertanggung jawab serta bertindak secara cerdas dalam kehidupan bermasyarakat, berbangsa, dan bernegara sehingga akan menciptakan karakter masyarakat Indonesia yang baik dan aktif dalam kehidupan antar bangsa dan Negara.

Dalam pembelajaran PPKn di Sekolah Menengah Atas, banyak materi yang wajib dibaca oleh siswa. Untuk memaksimalkan pemahaman siswa tentunya tidak hanya bisa dilakukan dari kegiatan membaca saja, namun juga kegiatan menulis hal-hal pokok yang terdapat pada materi, sehingga siswa dengan mudah memahami materi tersebut.

Realita yang terjadi pada pembelajaran PPKn di kelas X MIA 2 SMAN 1 Denpasar adalah masih banyaknya siswa yang kurang berminat dalam membaca dan menulis dari kesimpulan materi pelajaran yang diberikan oleh guru, sehingga siswa kurang memahami pembelajaran dan berdampak negatif terhadap hasil belajar siswa. Hal ini ditunjukkan dari rata-rata hasil belajar PPKn siswa di kelas X MIA 2 SMAN 1 Denpasar adalah sebesar 63,61.

Salah satu model yang dapat diterapkan guru dalam pembelajaran PPKn adalah model pembelajaran CIRC (Coperative Integrated Reading And Composition). Model pembelajaran CIRC (Cooperative Integratited Reading and Composition) merupakan salah satu model dari pelajaran kooperatif. pembelajaran kooperatif sesuai dengan hakikat manusia sebagai mahluk sosial yang penuh ketergantungan dengan orang lain, mempunyai tujuan dan tanggung jawab bersama, pembagian tugas dan rasa senasib. Dengan memanfaatkan kenyataan itu, belajar kelompok secara kooperatif, siswa dilatih dibiasakan untuk saling (sharing) pengetahuan, pengalaman, tugas, tanggung jawab, saling membantu dan berlatih berinteraksi, berkomunikasi, serta bersosialisasi karena kooperatife adalah miniature dari hidup bermasyarakat dan belajar menyadari kekurangan dan kelebihan masing-masing.

Guru Adalah Suatu Sebutan Bagi Jabatan, Posisi, Dan Profesi Bagi Seseorang Yang Mengabdikan Dirinya Dalam Bidang Pendidikan Melalui Interaksi Edukatif Secara Terpola, Formal, Dan Sistematis. Dalam UU R.I. Nomor 14 Tahun 2005 Tentang Guru Dan Dosen Pada Bab I Pasal 1 Dinyatakan Bahwa: Guru Adalah Pendidik Profesional Dengan Tugas Utama Mendidik, Mengajar, Membimbing, Mengarahkan, Melatih, Menilai, Dan Mengevaluasi Peserta Didik Pada Pendidikan Anak Usia Dini Jalur Pendidikan Formal, Pendidikan Dasar, Dan Pendidikan Menengah. (Redaksi Sinar Grafika, 2009:3) .

Guru yang profesional akan tercermin dalam penampilan pelaksanaan pengabdian tugas-tugas yang ditandai dengan keahlian, baik dalam materi maupun metode. Di samping keahliannya, sosok guru profesional ditunjukkan melalui tanggung jawabnya dalam melaksanakan seluruh pengabdiannya. Guru profesional hendaknya mampu memikul dan melaksanakan tanggung jawabnya sebagai guru kepada peserta didik, orang tua, masyarakat, bangsa, negara, dan agamanya. Sebagai pengajar atau pendidik, guru merupakan salah satu faktor penentu keberhasilan setiap upaya pendidikan. Itulah sebabnya setiap adanya inovasi pendidikan, khususnya dalam kurikulum dan peningkatan sumber daya manusia yang dihasilkan dari upaya pendidikan, selalu bermuara pada faktor guru. Hal ini menunjukkan bahwa betapa eksisnya peran guru dalam dunia pendidikan. Guru menjadi faktor yang menentukan mutu pendidikan karena guru berhadapan langsung dengan para peserta didik dalam proses pembelajaran di kelas. Di tangan guru, mutu dan kepribadian peserta didik dibentuk. Karena itu, perlu sosok guru kompeten, bertanggung jawab, terampil, dan berdedikasi tinggi. Guru adalah kurikulum berjalan. Sebaik apa kurikulum dan sistem pendidikan yang ada tanpa didukung oleh kemampuan guru, semuanya akan siasia. Guru berkompeten dan bertanggung jawab, utamanya dalam mengawal perkembangan peserta didik sampai ke suatu titik maksimal. Tujuan akhir seluruh proses pendampingan guru adalah tumbuhnya pribadi dewasa yang utuh. Seiring dengan kemajuan teknologi informasi yang begitu pesat, guru tidak lagi sekedar bertindak sebagai penyaji informasi. Guru juga harus mampu bertindak sebagai fasilitator, motivator, dan pembimbing yang lebih banyak memberikan kesempatan kepada peserta didik untuk mencari dan mengolah sendiri informasi (Uno, 2009:16-17). Dengan demikian, guru juga harus senantiasa 
meningkatkan keahliannya dan senantiasa mengikuti perkembangan ilmu pengetahuan dan teknologi sehingga ia mampu menghadapi berbagai tantangan. Perkembangan dunia pendidikan yang sejalan dengan kemajuan teknologi dan globalisasi yang begitu cepat perlu diimbangi oleh kemampuan pelaku utama pendidikan, dalam hal ini guru. Bagi sebagian guru, menghadapi perubahan yang cepat dalam pendidikan dapat membawa dampak kecemasan dan ketakutan. Perubahan dan pembaruan pada umumnya membawa banyak kecemasan dan ketidaknyamanan. Implikasi perubahan dalam dunia pendidikan, bukan perkara mudah, karena mengandung konsekwensi teknis dan praksis, serta psikologis bagi guru. Misalnya, perubahan kurikulum atau perubahan kebijakan pendidikan. Perubahan itu tidak sekedar perubahan struktur dan isi kurikulum (Shabir, 2015).

Model pembelajaran CIRC memiliki kelebihan yaitu 1) dapat lebih memahami bacaan/wacana dan tidak bergantung pada teks tertentu, 2) dapat meningkatkan kemampuan siswa dalam memberikan suatu solusi terhadap suatu permasalahan yang diberikan oleh guru, 3) dapat digunakan untuk siswa yang memiliki tingkat kemampuan rendah, 4) meningkatkan aktivitas siswa dalam proses pembelajaran, 5) meningkatkan rasa percaya diri siswa karena mereka bisa menemukan konsep dari materi yang dipelajari dan dapat menyampaikan di depan kelas.

Berdasarkan uraian di atas, maka penulis tertarik untuk melakukan penelitian dangan judul Penerapan Model Pembelajaran CIRC (Cooperative Integrated Reading And Composition)_untuk Meningkatkan Hasil Belajar PPKn Siswa Kelas X MIA 2 SMAN 1 Denpasar semester II Tahun Pelajaran 2018/2019.

\section{Metode}

Penelitian ini dilaksanakan pada semester II tahun pelajaran 2018/2019 di SMAN 1 Denpasar dari bulan Pebruari sampai dengan Mei 2019. Kegiatan Penelitian Tindakan Kelas ini dilakukan di SMAN 1 Denpasar. Subjek penelitian ini adalah siswa kelas X MIA 2 semester II tahun pelajaran 2018/2019 yang berjumlah 36 orang. Sedangkan objek dari penelitian ini adalah Hasil Belajar PPKn setelah penerapan model pembelajaran CIRC.

Jenis penelitian ini adalah penelitian tindakan kelas (PTK). PTK merupakan suatu bentuk penelitian yang bersifat reflektif dengan melakukan tindakan-tindakan tertentu agar dapat memperbaiki dan atau meningkatkan praktek-praktek pembelajaran di kelas secara lebih professional. PTK merupakan penelitian bersifat aplikasi (terapan), terbatas, segera, dan hasilnya untuk memperbaiki dan menyempurnakan proses atau program pembelajaran yang sedang berjalan (dalam Agung, 2011:23).

Penelitian ini akan dilaksanakan dalam beberapa siklus yang setiap siklus akan dilaksanakan sebanyak tiga kali pertemuan. Pertemuan pertama dan kedua untuk pembahasan materi pembelajaran, sedangkan pertemuan ketiga untuk pemberian tes evaluasi. Tiap siklus terdiri dari empat tahapan yaitu: Perencanaan, Pelaksanaan Tindakan, Observasi dan Evaluasi Tindakan, dan Refleksi. Masing-masing tahapan tersebut dapat dijelaskan sebagai berikut

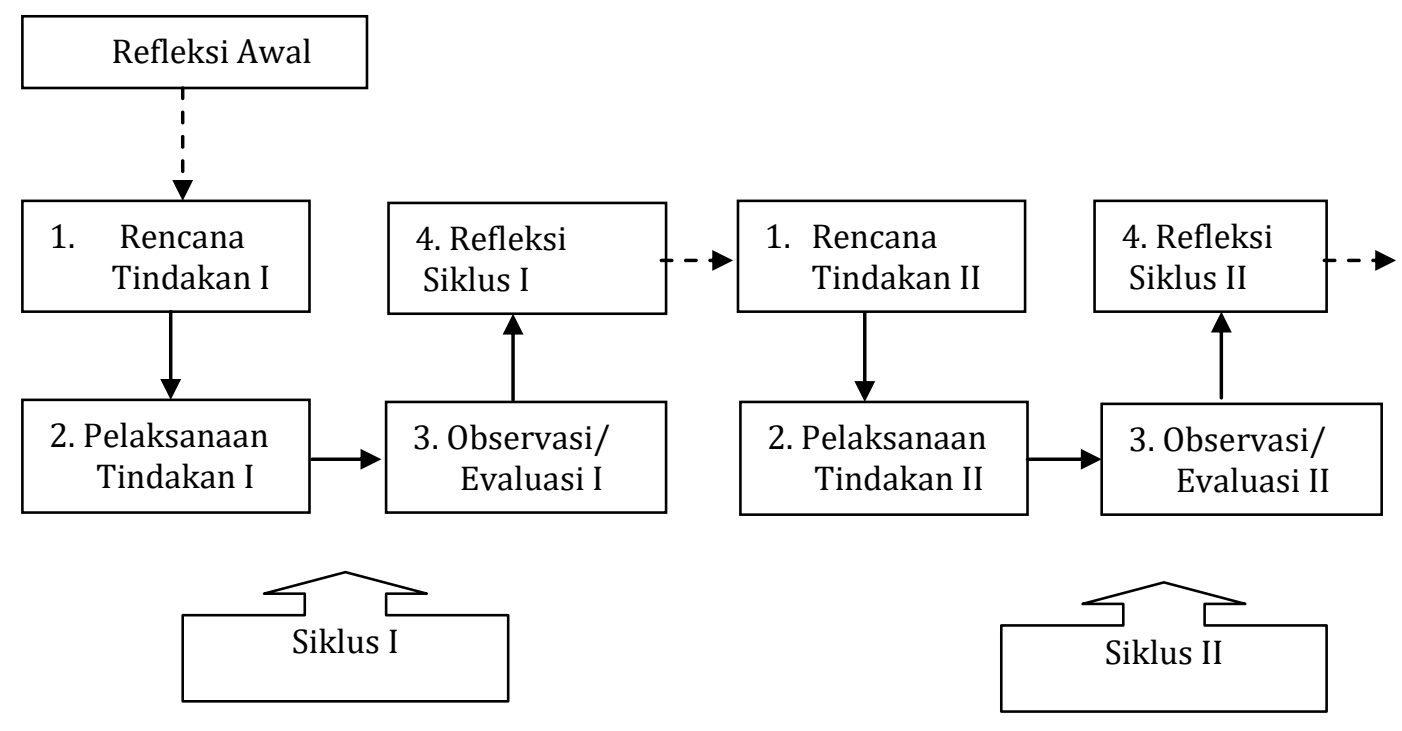

Gambar 1. Model Penelitian Tindakan Kelas Dua Siklus

Sumber: Agung, 2011 
Penelitian ini diawali dengan refleksi awal yang bertujuan untuk mengidentifikasi permasalahanpermasalahan dan kendala-kendala yang dialami siswa dalam proses pembelajaran PPKn, serta kelemahan-kelemahan model atau metode pembelajaran yang diterapkan selama ini. Melalui refleksi awal ini, peneliti dapat mengetahui hal-hal apa saja yang perlu dilakukan pada tahap perencanaan tindakan.

1) Perencanaan Tindakan

Beberapa hal yang perlu disiapkan pada tahap perencanaan adalah sebagai berikut.

(a) Menentukan materi/pokok bahasan yang akan dibahas.

(b) Menyusun perangkat pembelajaran, yaitu RPP sebagai pedoman untuk melaksanakan proses pembelajaran, media pembelajaran, dan instrumen pengumpulan data, seperti lembar observasi dan tes hasil belajar.

2) Pelaksanaan Tindakan

Pelaksanaan tindakan dilakukan sebanyak 3 kali pertemuan. Pelaksanaan tindakan yang dilakukan disesuaikan dengan RPP yang telah disusun. Tindakan yang dilakukan untuk meningkatkan adalah Hasil Belajar PPKn siswa kelas X MIA 2 semester II tahun pelajaran 2018/2019 setelah implementasi model pembelajaran CIRC.

3) Observasi dan Evaluasi Tindakan

Kegiatan evaluasi dilaksanakan selama proses pembelajaran berlangsung. Data tentang hasil belajar PPKn siswa dalam pembelajaran dikumpulkan dengan tes hasil belajar PPKn siswa.

4) Refleksi

Kegiatan refleksi ini berusaha mencari alur pemikiran yang logis, permasalahan, dan hambatan yang muncul dalam pelaksanaan tindakan. Selain itu, kegiatan refleksi berguna untuk melakukan peninjauan, membuat gambaran kerja, yang hidup dalam situasi proses penelitian, hambatan yang muncul dalam tindakan dan kemungkinan lain yang muncul selama proses penelitian.

Penelitian ini menggunakan metode tes. Metode tes merupakan cara memperoleh data yang berbentuk tugas yang harus dilakukan atau dikerjakan oleh seorang atau sekelompok orang yang dites (testee), yang dapat menghasilkan suatu data berupa skor (Agung, 2011:60). Skor yang dihasilkan merupakan data interval. Tes yang dibuat berbentuk pilihan ganda dengan empat buah pilihan.

Setelah data dalam penelitian ini terkumpul maka selanjutnya dilakukan analisis data. Analisis data ini menggunakan metode analisis statistik deskriptif kuantitatif. Agung (2011:61) menyatakan bahwa: "metode analisis deskriptif kuantitatif adalah suatu cara pengolahan data yang dilakukan dengan jalan menyusun secara sistematis dalam bentuk angka-angka atau persentase mengenai keadaan suatu objek yang diteliti sehingga diperoleh kesimpulan umum".

Metode analisis deskriptif kuantitatif ini digunakan untuk menentukan tingkatan tinggi rendahnya Prestasi Belajar PPKn siswa yang dikonversikan ke dalam Penilaian Acuan Patokan (PAP) skala lima.

Tingkatan Prestasi Belajar PPKn siswa dapat ditentukan dengan membandingkan M\% atau ratarata persen ke dalam PAP skala lima dengan kriteria sebagai berikut.

Tabel 1. Pedoman Konversi PAP Skala Lima

\begin{tabular}{cl}
\hline Persentase & \multicolumn{1}{c}{ Kriteria Hasil Belajar Ilmu Pengetahuan Sosial } \\
\hline $90-100$ & Sangat Baik \\
$75-89$ & Baik \\
$65-74$ & Cukup \\
$40-64$ & Kurang \\
$0-39$ & Sangat Kurang \\
\hline
\end{tabular}

Sumber: Agung, 2011

Indikator keberhasilan pelaksanaan ini, berpedoman pada tingkat keberhasilan dalam penelitian ini adalah apabila Hasil Belajar PPKn siswa memenuhi KKM sekolah yakni minimal 70, dan ketuntasan klasikal sebesar $90 \%$.

\section{Hasil dan Pembahasan}

Pendidikan kewaganegaraan merupakan bidang studi yang mencakup lintas bidang keilmuan karena dalam pendidikan kewarganegaraan terdapat pula pokok ilmu politik kemudian berkembang konsep civics yang berarti warga negara kemudian berkembang menjadi civics education yang selanjutnya diadaptasi menjadi pendidikan kewarganegaraan.

Pendidikan kewarganegaraan di sekolah bertujuan menghasilkan peserta didik yang memiliki budi pekerti dan selalu berpikir kritis dalam menanggapi isu kewarganegaraan serta selalu berpartisipasi aktif 
dan bertanggung jawab serta bertindak secara cerdas dalam kehidupan bermasyarakat, berbangsa, dan bernegara sehingga akan menciptakan karakter masyarakat Indonesia yang baik dan aktif dalam kehidupan antar bangsa dan Negara.

Dalam pembelajaran PPKn di Sekolah Menengah Atas, banyak materi yang wajib dibaca oleh siswa. Untuk memaksimalkan pemahaman siswa tentunya tidak hanya bisa dilakukan dari kegiatan membaca saja, namun juga kegiatan menulis hal-hal pokok yang terdapat pada materi, sehingga siswa dengan mudah memahami materi tersebut.

Salah satu model pembelajarna yang dapat diterapkan yakni model pembelajaran CIRC. Model pembelajaran CIRC memiliki kelebihan yaitu 1) dapat lebih memahami bacaan/wacana dan tidak bergantung pada teks tertentu, 2) dapat meningkatkan kemampuan siswa dalam memberikan suatu solusi terhadap suatu permasalahn yang diberikan oleh guru, 3) dapat digunakan untuk siswa yang memiliki tingkat kemampuan rendah, 4) meningkatkan aktivitas siswa dalam proses pembelajaran, 5) meningkatkan rasa percaya diri siswa karena mereka bisa menemukan konsep dari materi yang dipelajari dan dapat menyampaikan di depan kelas.

Berdasarkan penelitian yang dilakukan pada siklus I, didapatkan rata-rata hasil belajar PPKn siswa sebesar 73,19, setelah dikonvesikan ke dalam PAP skala lima, berada pada interval 65 - 74\% yang berarti bahwa tingkat hasil belajar PPKn siswa siklus I tergolong cukup. Selain itu data yang juga diperoleh dari hasil analisis data yakni skor minimum yang diperoleh siswa sebesar 50, skor maksimum sebesar 90, median sebesar 75, dan modus sebesar 80. dilihat dari ketuntasan klasikalnya didapatkan sebesar $=$ $77,78 \%$. Hal itu dikarenakan 8 orang siswa masih memiliki hasil belajar PPKn dibawah nilai 70, sehingga masih dibawah KKM yang telah ditetapkan peneliti.

Penyebab masih adanya siswa yang mendapatkan skor di bawah KKM yang telah ditetapkan oleh peneliti disebabkan karena ada beberapa siswa yang masih kurang mau membaca materi yang diberikan oleh guru dengan baik, sehingga siswa kurang memahami materi yang dipelajarinya.

Untuk mengatasi permasalahan di atas, maka siklus dilanjutkan pada siklus II. Pada siklus II, guru lebih menekankan kegiatan membaca materi siswa pada pelajaran PPKn, sehingga materi yang dipelajari siswa dapat dipahami dengan maksimal.

Berdasarkan penelitian yang telah dilakukan pada siklus II, terlihat ada perkembangan dan peningkatan hasil belajar PPKn yang sangat baik. Hal tersebut tercermin dari peningkatan skor minimum yang dicapai oleh siswa yakni sebesar 65, skor maksimum sebesar 100, rata-rata hasil belajar PPKn siswa sebesar 86,25, median sebesar 90, dan modus sebesar 90. Selain itu peningkatan juga terjadi pada ketuntasan klasikal siswa yakni menjadi 91,67\%.

Hasil di atas mengindikasikan penelitian yang telah dilakukan oleh peneliti berhasil. Hal itu dikarenakan KKM yang telah ditetapkan oleh peneliti sudah tercapai. Maka dari itu, siklus dihentikan sampai siklus II.

Peningkatan rerata dan ketuntasan klasikal dari siklus I sampai siklus II dapat digambarkan sebagai berikut.

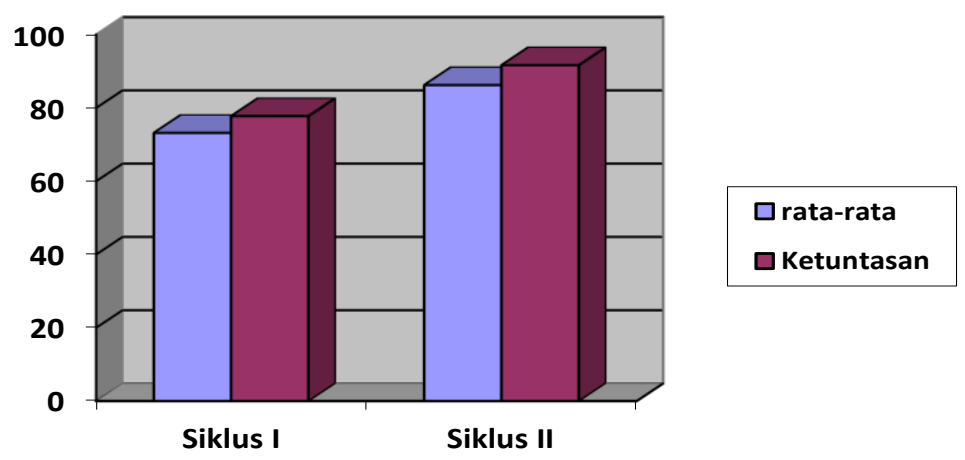

Gambar 2. Peningkatan Rerata dan Ketuntasan Klasikal

Hasil penelitian ini sejalan dengan penelitian yang dilakukan oleh Harniyati (2019) yang berjudul Meningkatkan Hasil Belajar PKN Pada Materi Nilai Dan Norma Sosial Melalui Pembelajaran CIRC (Cooperative, Integrated, Reading, And Composition) Pada Siswa Kelas X Multimedia SMK Negeri 3 Watampone Kabupaten Bone. Dalam penelitiannya dinyatkan bahwa: terjadi perubahan perilaku siswa yang mengalami peningkatan dengan persentase pada siklus I hanya 94,2 \% dan pada siklus II meningkat 
menjadi $95,71 \%$ terjadi pula peningkatan perhatian, minat dan motivasi siswa terhadap materi pelajaran yang diberikan oleh guru. Dari analisis tersebut maka dapat disimpulkan bahwa hasil belajar PKn siswa Kelas X Multimedia SMK Negeri 3 Watampone mengalami peningkatan setelah diberikan tindakan melalui model pembelajaran CIRC (Cooperative, Integrated, reading and Composition).

\section{Simpulan Dan Saran}

Penelitian Berdasarkan pembahasan yang telah dikemukakan pada bab sebelumnya, maka dapat diambil simpulan sebagi berikut. Penerapan model pembelajaran CIRC (Cooperative Integrated Reading And Composition) secara efektif dapat meningkatkan hasil belajar PPKn siswa kelas X MIA 2 semester II di SMAN 1 Denpasar tahun pelajaran 2018/2019. Hal tersebut ditunjukkan dari rerata pada siklus I sebesar 73,19 dengan ketuntasan klasikal 77,78\%. Sedangkan rerata pada siklus II sebesar 86,25 dengan ketuntasan klasikal 91,67\%.

Berdasarkan simpulan di atas, disarankan hal-hal sebagai berikut. Siswa disarankan untuk selalu meningkatkan intensitas membacanya, sehingga wawasan siswa dapat bertambah dan berdampak positif terhadap hasil belajar siswa.

Guru disarankan untuk memberikan wadah kepada siswa untuk membaca materi seluas-luasnya, dikarenakan kegiatan membaca sangat positif untuk meningkatkan kemampuan dan wawasan siswa.Kepala sekolah disarankan untuk mengambil kebijakan-kebijakan yang mampu meningkatkan SDM guru maupun siswa.Peneliti lain disarankan mengembangkan penelitian ini dengan menggunakan variabel yang lebih kompleks, sehingga permasalahan di dunia pendidikan dapat diminimalkan.

\section{Daftar Rujukan}

Agung, A.A. Gede. 2005. Metodologi Penelitian Pendidikan, suatu pengantar. Singaraja : FIP Undiksha Singaraja.

Agung, A. A. G. 2011. Metodelogi Penelitian Pendidikan. Singaraja: Fakultas Ilmu Pendidikan Universitas Pendidikan Ganesha.

Ayu, Nanda. 2017. Pendidikan Karakter Sebagai Pilar Pembentukan Karakter Bangsa . Jurnal Fakultas Ilmu Sosial Universitas Negeri Medan Tahun 2017 Vol. 1 No. 1 2017, Hal. 348-352

BUNP. 2011. Standar Kompetensi dan Kompetensi Dasar Sekolah Menengah Atas/Madrasah Ibtidaiyah. Jakarta: Kemendiknas.

Harniyati. 2019. Meningkatkan Hasil Belajar PKN Pada Materi Nilai Dan Norma Sosial Melalui Pembelajaran CIRC (Cooperative, Integrated, Reading, And Composition) Pada Siswa Kelas X Multimedia SMK Negeri 3 Watampone Kabupaten Bone. Jurnal Ilmiah Ilmu Kependidikan. Vol,3. No,1. Tahun 2019 e-ISSN: 2597-4440 dan p-ISSN: 2597-4424.

Fitriani, Cut. 2017. Kompetensi Profesional Guru Dalam Pengelolaan Pembelajaran Di MtsMuhammadiyah Banda Aceh . Jurnal Magister Administrasi Pendidikan ISSN 2302-0156

Ihsan. 2017. Kecenderungan Global Dalam Proses Pembelajaran Pendidikan Pancasila Dan Kewarganegaraan Di Sekolah. Jurnal Pancasila dan Kewarganegaraan, Vol. 2, No. 2, Juli 2017 ISSN 2527-7057

Nurkancana. Wayan dan Sunartana. 1990. Evaluasi Hasil Belajar. Surabaya: Usaha Nasional

Rahim, Farida. 2008. Pengajaran Membaca Sekolah Menengah Atas. Jakarta: Bumi Aksara

Shabir,M. 2015. Kedudukan Guru Sebagai Pendidik: (Tugas Dan Tanggung Jawab, Hak Dan Kewajiban, Dan Kompetensi Guru) . Jurnal Auladuna, Vol. 2 No. 2 Desember 2015: 221-232

Slavin, Robert. 2005. Cooperative Learning. Bandung: Nusa Media.

Siregar, Evaline. 2011. Teori Belajar dan Pembelajaran. Bogor 
Uno, Hamzah. 2011. Belajar dengan Pendekatan PAILKEM. Jakarta: Bumi Aksara.

Sunal, C.S. \& Haas, M. 1993. Social Studies and the Elementary/Middle School Student. Fort Worth: Harcourt Brace Jovanovich College Publishers.

Winataputra, Udin S. 2001. Jati Diri Pendidikan Kewarganegaraan sebagai Wahana Pendidikan Demokrasi. Disertasi pada Program Pasca Sarjana UPI Bandung.

Widodo. 2013. Peningkatan Aktivitas Belajar Dan Hasil Belajar Siswa Dengan Metode Problem Based Learning Pada Siswa Kelas Viia Mts Negeri Donomulyo Kulon Progo Tahun Pelajaran 2012/2013 . Jurnal Fisika Indonesia No: 49, Vol XVII, Edisi April 2013 ISSN : 1410-2994 